\title{
KAJIAN FAKTOR PENYEBAB KERUSAKAN TANAH DALAM MEMPRODUKSI BIOMASSA DI KECAMATAN PADAS KABUPATEN NGAWI
}

\author{
Sumarno ${ }^{1)}$, Purwanto ${ }^{2)}$, Sely Rakhmawati ${ }^{3)^{*}}$ \\ 1) Staf Dosen Program Studi Ilmu Tanah, Fakultas Pertanian, Universitas Sebelas Maret \\ 3) Mahasiswa S1 Program Studi Agroteknologi, Fakultas Pertanian, Universitas Sebelas Maret \\ Author contact: ohsely25@gmail.com
}

\begin{abstract}
Soil deterioration for biomass production caused by soil processing out of control and that can make the soil quality become decrease. The research aims to map out soil potention and status for biomass production as a reference for government in Padas sub-district to preserve and repair soil quality. The research aims to map of potention and status of soil deterioration as a reference for government in Padas sub-district, so they can preserve and repair soil quality. This research was conducted using a survey method, with observations, take the soil samples for laboratory analyses and then scoring and matching from result of analyses to determine soil status. The result of this research showed Parameters contributing to soil damage in Kecamatan Padas are permeability in all unit of land maps, texture parameters in unit of land maps 2, 3, and 4, then soil redox parameters in unit of land maps 3 and 5 . This is because the soil texture has a high klei content so that the ability to withstand high water which causes low permeability values and soil conditions that are water-saturated or inundated will result in a low soil redox value or $<200 \mathrm{mV}$. Padas sub-district Ngawi regency is include into minor damage status or RI with 5 total score based on the Government Regulation No. 150 of 2000.
\end{abstract}

Keywords: Soil Processing, Soil Deterioration, Biomass

AGROTECHNOLOGY RESEARCH JOURNAL

Sumarno, Purwanto, Rakhmawati S. 2018. The study of factors affecting to soil deteration for biomass production in padas sub-district ngawi regency. Agrotech Res J 2(1): 35-40.

Sumarno, Purwanto, Rakhmawati S. 2018. Kajian faktor penyebab kerusakan tanah dalam memproduksi biomassa di kecamatan padas kabupaten ngawi. Agrotech Res J 2(1): 35-40.

\section{PENDAHULUAN}

Indonesia merupakan salah satu negara dengan jumlah penduduk terbesar. Hasil Survei Penduduk Antar Sensus (SUPAS) 2015 oleh BPS menunjukkan bahwa jumlah penduduk Indonesia pada tahun 2015 mencapai 255.182.144 jiwa atau mengalami peningkatan dari tahun 2014 yang hanya 252.164.800 jiwa. Pertumbuhan jumlah penduduk yang pesat mempengaruhi peningkatan kebutuhan.

Tingkat kebutuhan yang semakin tinggi dengan laju pertumbuhan penduduk yang terus bertambah menyebabkan sumberdaya energi semakin menipis dan tidak mampu memenuhi kebutuhan masyarakat sehingga tanah tempat melangsungkan kehidupan manusia juga akan terganggu. Tanah adalah benda alami yang terletak di permukaan sampai kedalaman tertentu, terdiri dari bahan mineral dan bahan organik yang mampu menumbuhkan tanaman untuk menghasilkan biomassa.

Menurut PERMENLH NO.07 Tahun 2006 biomassa adalah tumbuhan atau bagian-bagiannya yaitu bunga, biji, buah, daun, ranting, batang, dan akar, termasuk tanaman yang dihasilkan oleh kegiatan pertanian, perkebunan, dan hutan tanaman. Kabupaten Ngawi dengan luas $1.295,58 \mathrm{~km}^{2}, 56$ persen dari luas wilayah adalah lahan pertanian (BPS Kab. Ngawi 2015). Tingginya usaha pertanian di Kabupaten Ngawi menunjukkan bahwa tingkat produksi biomassa juga meningkat dengan berbagai pengolahan tanah.

${ }^{*}$ Fak. Pertanian UNS Surakarta

JI. Ir. Sutami 36 A Surakarta
Pengolahan dan pemanfaatan tanah yang tidak terkendali dapat menyebabkan terjadinya kerusakaan tanah yang berdampak pada menurunya fungsi dan kualitas tanah. Kualitas tanah adalah kemampuan tanah untuk melakukan fungsi-fungsi penting tanah sebagai media tanam (De la Rosa 2005). Kualitas tanah bervariasi disebabkan oleh variasi komponennya. Tidak semua jenis tanah yang cocok untuk semua jenis tanaman (Abdul Khalil et al. 2015). Kualitas tanah perlu untuk dijaga untuk menghasilkan biomassa yang maksimal. Penelitian ini bertujuan untuk mengetahui parameter menyebabkan kerusakan tanah di Kecamatan Padas, Kabupaten Ngawi dan untuk mengetahui status kerusakan tanah untuk produksi biomassa di Kecamatan Padas, Kabupaten Ngawi.

\section{METODE PENELITIAN}

Penelitian dilaksanakan bulan Mei- Juni 2017 di Desa Bendo, Banjarsari, Pacing, Munggut, Sukowiyono, dan Tambakromo Kacamatan Padas Kabupaten Ngawi Provinsi Jawa Timur dan analisis tanah dilakukan di Laboratorium Fisika dan Konservasi Tanah, Laboratorium Kimia dan Kesuburan Tanah dan Laboratorium Biologi Tanah Fakultas Pertanian Universitas Sebelas Maret Surakarta.

Penelitian dilakukan dengan metode survei. Data yang digunakan dalam penelitian ini berasal dari data primer (pengamatan secara langsung dan hasil analisis laboratorium) dan data sekunder. Tahapan dalam pelaksanaan penelitian ini antara lain 1) Persiapan dan penyusunan peta kerja, 2) Pembuatan potensi kerusakan tanah, 3) Survei dan pengambilan sampel yang selanjutnya akan dilakukan analisis laboratorium, 
dan 4) Penetapan status kerusakan tanah dengan cara matching dan skoring (Kementerian Negara Lingkungan Hidup 2009).

\section{Persiapan dan penyusunan peta kerja}

Identifikasi kondisi awal tanah dilakukan untuk mengetahui areal yang berpotensi mengalami kerusakan. Menentuan satuan peta lahan (SPL) dimulai dengan membuat peta kerja untuk panduan pengambilan sampel tanah dilakukan dengan cara melakukan tumpang susun (overlay) peta-peta tematik yang digunakan sebagai peta kerja yang meliputi peta penggunaan lahan, peta jenis tanah, dan pleta kemiringan lereng wilayah penelitian.

\section{Pembuatan potensi kerusakan tanah}

Mengelompokan akumulasi atau jumlah dari bobot masing-masing peta temakik dengan hasil kali nilai skor. Nilai skor yaitu nilai yang diperoleh dari hasil perkalian nilai rating dengan nilai bobot, sedang nilai rating merupakan nilai potensi dari masing-masing unsur dari peta tematik. Kelas potensi rusak tanah (Tabel 1) dibagi menjadi 5 yaitu potensi sangat rendah, rendah, sedang, tinggi, dan sangat tinggi sesuai dengan Pedoman Teknis Penyusunan Status Kerusakan Tanah untuk Produksi Biomassa dari Kementerian Lingkungan Hidup Tahun 2009.

Tabel 1 Kriteria pembagian kelas potensi kerusakan tanah berdasarkan nilai skor

\begin{tabular}{llc}
\hline Simbol & $\begin{array}{c}\text { Potensi } \\
\text { kerusakan tanah }\end{array}$ & Skor pembobotan \\
\hline PR. I & Sangat ringan & $<15$ \\
PR. II & Ringan & $15-24$ \\
PR. III & Sedang & $25-34$ \\
PR. IV & Tinggi & $35-44$ \\
PR. V & Sangat tinggi & $45-50$ \\
\hline
\end{tabular}

Sumber: Kementrian Lingkungan Hidup Tahun 2009

\section{Survei dan pengambilan sampel yang selanjutnya akan dilakukan analisis laboratorium}

Metode pengambilan contoh tanah dilakukan dengan 2 cara yaitu, terusik dan tidak terusik. Analisis sifat-sifat tanah di laboratorium dari contoh tanah terusik dan tak terusik yang diambil dari lapangan untuk menentukan kriteria tingkat kerusakan tanah berdasarkan kriteria baku kerusakan tanah pada Peraturan Pemerintah No 150 Tahun 2000.

\section{Penetapan status kerusakan tanah dengan cara matching dan skoring}

Matching yaitu membandingkan antara data yang diperoleh baik dari hasil survei maupun data hasil analisis laboratorium dengan kriteria baku kerusakan tanah (Tabel 2) berdasarkan PP No. 150 Tahun 2000.

Tabel 2 Kriteria baku kerusakan tanah untuk lahan kering

\begin{tabular}{|c|c|c|}
\hline No & Parameter & Ambang kritis \\
\hline 1 & Ketebalan solum & $<20 \mathrm{~cm}$ \\
\hline 2 & $\begin{array}{l}\text { Kebatuan } \\
\text { permukaan }\end{array}$ & $>40 \%$ \\
\hline 3 & Komposisi & $<18 \%$ koloid; Lempung \\
\hline
\end{tabular}

\begin{tabular}{|c|c|c|}
\hline No & Parameter & Ambang kritis \\
\hline & pasir & $\begin{array}{l}>80 \% \text { pasir kuarsatik } \\
\text { Pasir Kasar }\end{array}$ \\
\hline 4 & Berat Volume (BV) & $>1,4 \mathrm{~g} / \mathrm{cm}^{3}$ \\
\hline 5 & Porositas total & $<30 \% ;>70 \%$ \\
\hline 6 & $\begin{array}{l}\text { Derajat pelulusan } \\
\text { air }\end{array}$ & $<0,7 \mathrm{~cm} / \mathrm{jam} ;>8 \mathrm{~cm} / \mathrm{jam}$ \\
\hline 7 & $\mathrm{pH}\left(\mathrm{H}_{2} \mathrm{O}\right) 1: 2,5$ & $<4,5 ;>8,5$ \\
\hline 8 & $\begin{array}{l}\text { Daya Hantar Listrik } \\
\text { (DHL) }\end{array}$ & $>4,0 \mathrm{mS} / \mathrm{cm}$ \\
\hline & $\begin{array}{l}\text { Redoks } \\
\text { Jumlah mikroba }\end{array}$ & $\begin{array}{l}<200 \mathrm{Mv} \\
<10^{2} \mathrm{cfu} / \mathrm{g} \text { tanah }\end{array}$ \\
\hline
\end{tabular}

Sumber: PP No. 150 Tahun 2000

Skoring kerusakan tanah (Tabel 3) dilakukan dengan menghitung frekuensi relatif kerusakan tanah dari hasil matching pada suatu luasan tertentu.

Tabel 3 Skor kerusakan tanah berdasarkan frekuensi relative dari berbagai parameter kerusakan tanah

\begin{tabular}{ccl}
\hline $\begin{array}{c}\text { Frekuensi Relatif } \\
\text { Tanah Rusak (\%) }\end{array}$ & Skor & $\begin{array}{c}\text { Status Kerusakan } \\
\text { Tanah }\end{array}$ \\
\hline $0-10$ & 0 & Tidak rusak \\
$11-25$ & 1 & Rusak ringan \\
$26-50$ & 2 & Rusak sedang \\
$51-75$ & 3 & Rusak berat \\
$76-100$ & 4 & Rusak sangat berat \\
\hline
\end{tabular}

Sumber: Kementerian Negara Lingkungan Hidup (2009)

Nilai skor masing-masing parameter kriteria baku kerusakan tanah dijumlahkan dan selanjutnya (Tabel 4) menetukan status kerusakan tanahnya.

Tabel 4 Status kerusakan tanah berdasarkan nilai akumulasi skor kerusakan tanah untuk lahan kering

\begin{tabular}{llr}
\hline Simbol & $\begin{array}{c}\text { Status Kerusakan } \\
\text { Tanah }\end{array}$ & $\begin{array}{c}\text { Akumulasi skor } \\
\text { kerusakan tanah } \\
\text { lahan kering }\end{array}$ \\
\hline N & Tidak rusak & 0 \\
R I & Rusak ringan & $1-14$ \\
R II & Rusak sedang & $15-24$ \\
R III & Rusak berat & $25-34$ \\
R IV & Rusak sangat berat & $35-40$ \\
\hline
\end{tabular}

Sumber: Kementerian Negara Lingkungan Hidup (2009)

\section{HASIL DAN PEMBAHASAN}

Hasil dari skoring wilayah Kecamatan Padas Kabupaten Ngawi untuk potensi kerusakan tanah rendah pada SPL 1 dan 4 dan potensi kerusakan tanah sangat rendah pada SPL 2,3,5, dan 6. Skoring setiap peta tematik dapat dilihat pada tabel 1. Peta potensi rusak (Gambar 1) menjelaskan tentang luas wilayah penelitian yang dihasilkan dari skor pembobotan potensi kerusakan tanah setiap peta tematik yang ada. Terdapat 2 kelas kerusakan tanah yaitu PR I (kerusakan sangat rendah) dan PR II (Kerusakan rendah) (Tabel 5).

Tabel 5 Potensial rusak satuan peta lahan (SPL) Kecamatan Padas

\begin{tabular}{ccc}
\hline SPL & Jumlah skor & Kelas potensi rusak \\
\hline 1 & 19 & PR. II \\
\hline
\end{tabular}




\begin{tabular}{ccc}
\hline SPL & Jumlah skor & Kelas potensi rusak \\
\hline 2 & 13 & PR. I \\
3 & 13 & PR. I \\
4 & 19 & PR. II \\
5 & 13 & PR. I \\
6 & 13 & PR. I \\
\hline
\end{tabular}

Sumber: Data sekunder

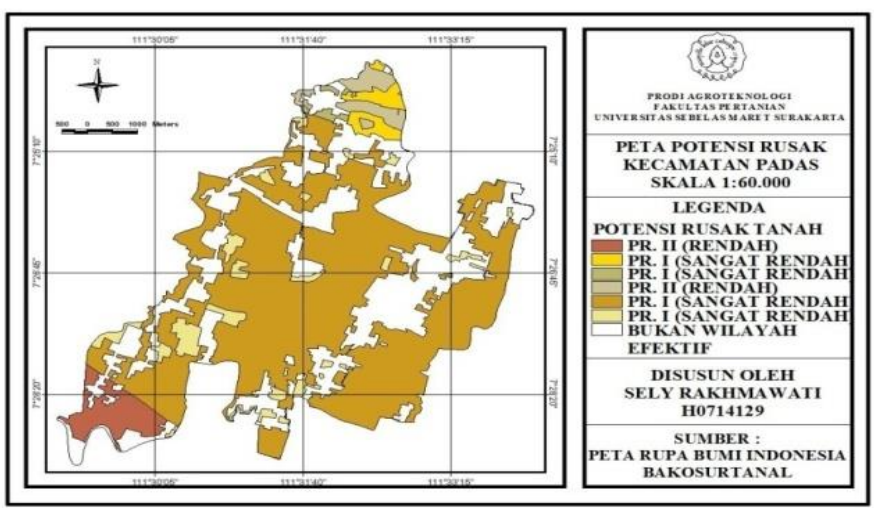

Gambar 1 Peta potensi rusak Kecamatan Padas Kabupaten Ngawi

Hasil analisis laboratorium dari sampel tanah dibandingkan dengan kriteria baku kerusakan tanah sesuai dengan Peraturan Pemerintah No.150 Tahun 2000. Hasil perbandingan analisis laboratorium dan kriteria baku kerusakan tanah (Tabel 6), menunjukkan bahwa pada parameter tekstur tanah terdapat 4 sampel tanah yang memiliki presentase fraksi klei $<18 \%$ sehingga tanah dikatakan dalam ambang kritis yang telah ditetapkan dan tidak ada sampel yang memiliki kandungan presentase fraksi pasir $>80 \%$.
Tindakan pengolahan tanah untuk produksi biomassa bukan merupakan penyebab kandungan pasir di lokasi pengambilan sampel rendah. Tanah di lokasi penelitian didominasi oleh fraksi klei karena tanah di lokasi penelitian termasuk tanah grumusol, sesuai pernyataan Foth (1994), tanah grumusol merupakan tanah mineral yang memiliki tanah liat 30 persen atau lebih dalam semua horison. Parameter permeabilitas terdapat 10 dari 18 sampel tanah lokasi penelitian termasuk dalam ambang kritis. Hasil penelitian oleh Yulnafatmawita et al. (2007) menyatakan bahwa terdapat tiga faktor yang mempengaruhi permeabilitas tanah, yaitu tekstur tanah, bahan organik, dan porositas. Semakin liat tanah maka akan semakin rendah laju permeabilitas tanah. Permeabilitas yang rendah mengakibatkan rendahnya laju masuknya air dari permukaan ke dalam profil tanah atau disebut dengan infiltrasi.

Lokasi pengambilan sampel terdapat 5 dari 18 titik sampel yang memiliki nilai redoks $<200 \mathrm{mV}$, sehingga dapat dikatakan 5 lokasi tersebut termasuk kriteria rusak. Nilai potensial redoks berhubungan erat dengan $\mathrm{pH}$ tanah. Kondisi reduksi-oksidasi terjadi pada tanah tergenang dapat mempengaruhi mangan di dalam tanah (Kusumaningtyas et al. 2015). Pernyataan tersebut didukung oleh Fahmi dan Hanudin (2008), tanah yang tergenang atau mengalami jenuh air akan mengalami kondisi reduksi sehingga konsentrasi oksigen dan laju difusi oksigen menjadi sangat rendah, laju difusi oksigen pada kondisi tergenang dapat mencapai 10.000 kali lebih lambat dari kondisi oksidatif. Tanah yang tergenang akan cenderung mengakibatkan potensial redoks tanah menjadi rendah (Suntari et. al 2003).

Tabel 6 Matching nilai parameter kerusakan tanah tiap satuan peta lahan Kecamatan Padas

\begin{tabular}{|c|c|c|c|c|c|c|c|c|c|c|c|c|c|c|c|}
\hline \multirow{2}{*}{ SPL } & \multirow{2}{*}{ Kode } & \multirow{2}{*}{$\begin{array}{l}\text { Kedalaman } \\
\text { Tanah/Sohmm } \\
(\mathrm{cm})\end{array}$} & \multirow{2}{*}{$\begin{array}{c}\text { Batuan } \\
\text { Permulka } \\
\text { an (9\%) }\end{array}$} & \multicolumn{4}{|c|}{ Komposisi fralksi ( $\%$ ) } & \multirow{2}{*}{$\begin{array}{l}\text { Jenis } \\
\text { tanah }\end{array}$} & \multirow{2}{*}{$\begin{array}{c}\text { Berat } \\
\text { volume } \\
(\mathrm{g} / \mathrm{cm})\end{array}$} & \multirow{2}{*}{$\underset{\text { tanah }}{\mathrm{pH}}$} & \multirow{2}{*}{$\begin{array}{c}\text { Red oks } \\
\operatorname{tanah} \\
(\mathrm{mV})\end{array}$} & \multirow{2}{*}{$\begin{array}{c}\text { Porosita } \\
S(\%)\end{array}$} & \multirow{2}{*}{$\underset{(\mathrm{mS} / \mathrm{cm})}{\mathrm{DHL}}$} & \multirow{2}{*}{$\begin{array}{c}\text { Derajat } \\
\text { pelulusan } \\
\text { air } \\
(\mathrm{cm} / \mathrm{jam})\end{array}$} & \multirow{2}{*}{$\begin{array}{c}\text { Total mikroba } \\
\text { tanah (cfu/g } \\
\text { tanah) }\end{array}$} \\
\hline & & & & Debu $9 \%$ & Klei $9 \%$ & Pasir $\%$ & Telsstur & & & & & & & & \\
\hline \multirow{3}{*}{1} & $1 \mathrm{UL} 1$ & $100 \mathrm{~N}$ & 0 & 28.47 & $64.34 \mathrm{~N}$ & $6.94 \mathrm{~N}$ & Liat & Inseptisol & $1.11 \mathrm{~N}$ & $6.51 \mathrm{~N}$ & $335 \mathrm{~N}$ & $45.32 \mathrm{~N}$ & $0.46 \mathrm{~N}$ & $3.47 \mathrm{~N}$ & $1.6 \times 10^{7} \mathrm{~N}$ \\
\hline & $1 \mathrm{UL} 2$ & $100 \mathrm{~N}$ & 0 & 13.56 & $69.46 \mathrm{~N}$ & $16.98 \mathrm{~N}$ & Liat & Inseptisol & $1 \mathrm{~N}$ & $6.62 \mathrm{~N}$ & $330 \mathrm{~N}$ & $45.85 \mathrm{~N}$ & $0.6 \mathrm{~N}$ & $0.51 \mathrm{R}$ & $3.9 \times 10^{\circ} \mathrm{N}$ \\
\hline & $1 \mathrm{UL}_{3}$ & $100 \mathrm{~N}$ & 0 & 23.02 & $76.56 \mathrm{~N}$ & $0.42 \mathrm{~N}$ & List & Inseptisol & $0.76 \mathrm{~N}$ & $7.15 \mathrm{~N}$ & $340 \mathrm{~N}$ & $45.11 \mathrm{~N}$ & $0.126 \mathrm{~N}$ & $O R$ & $3.05 \times 10^{8} \mathrm{~N}$ \\
\hline \multirow{3}{*}{2} & 2 UL 1 & $70 \mathrm{~N}$ & 0 & 45.47 & $34.34 \mathrm{~N}$ & $19.17 \mathrm{~N}$ & $\begin{array}{l}\text { Lempung lis } \\
\text { berdebu }\end{array}$ & Vertisol & $1.08 \mathrm{~N}$ & $7.19 \mathrm{~N}$ & $240 \mathrm{~N}$ & $52.21 \mathrm{~N}$ & $0.15 \mathrm{~N}$ & $0.16 \mathrm{R}$ & $2.8 \times 10^{7} \mathrm{~N}$ \\
\hline & $2 \mathrm{UL}_{2}$ & $70 \mathrm{~N}$ & 0 & 54.63 & $9.05 \mathrm{R}$ & $36.315 \mathrm{~N}$ & $\begin{array}{l}\text { Lempung } \\
\text { berdebu }\end{array}$ & Vertisol & $1.1 \mathrm{~N}$ & $7.28 \mathrm{~N}$ & $242 \mathrm{~N}$ & $49.59 \mathrm{~N}$ & $0.123 \mathrm{~N}$ & $1.37 \mathrm{~N}$ & $3.2 \times 10^{\circ} \mathrm{N}$ \\
\hline & 2 UL 3 & $70 \mathrm{~N}$ & 0 & 61.77 & $11.65 \mathrm{R}$ & $26.59 \mathrm{~N}$ & $\begin{array}{l}\text { Lempung } \\
\text { berdebu }\end{array}$ & Vertisol & $1.16 \mathrm{~N}$ & $7.34 \mathrm{~N}$ & $240 \mathrm{~N}$ & $49.51 \mathrm{~N}$ & $0.124 \mathrm{~N}$ & $O R$ & $3.9 \times 10^{\circ} \mathrm{N}$ \\
\hline \multirow{3}{*}{3} & $3 \mathrm{UI} 1$ & $60 \mathrm{~N}$ & 0 & 34.35 & $47.23 \mathrm{~N}$ & $17.31 \mathrm{~N}$ & Liat & Vertisol & $1.13 \mathrm{~N}$ & $6.79 \mathrm{~N}$ & $166 \mathrm{R}$ & $48.64 \mathrm{~N}$ & $0.22 \mathrm{~N}$ & $0.35 \mathrm{R}$ & $8.2 \times 10^{\circ} \mathrm{N}$ \\
\hline & 3 UL 2 & $60 \mathrm{~N}$ & 0 & 75.20 & $12.82 \mathrm{R}$ & $11.98 \mathrm{~N}$ & $\begin{array}{l}\text { Lempung } \\
\text { berdebu }\end{array}$ & Vertisol & $1.29 \mathrm{~N}$ & $7.54 \mathrm{~N}$ & $160 \mathrm{R}$ & $47.42 \mathrm{~N}$ & $0.112 \mathrm{~N}$ & $0.49 \mathrm{R}$ & $7.1 \times 10^{7} \mathrm{~N}$ \\
\hline & 3 UL 3 & $60 \mathrm{~N}$ & 0 & 48.10 & $28.76 \mathrm{~N}$ & $23.14 \mathrm{~N}$ & $\begin{array}{l}\text { Lempung } \\
\text { berliat }\end{array}$ & Vertisol & $1.07 \mathrm{~N}$ & $7.22 \mathrm{~N}$ & $163 \mathrm{R}$ & $53.28 \mathrm{~N}$ & $0.095 \mathrm{~N}$ & $\mathrm{OR}$ & $6.05 \times 10^{\circ} \mathrm{N}$ \\
\hline \multirow{3}{*}{4} & 4 UL 1 & $60 \mathrm{~N}$ & 0 & 37.90 & $32.23 \mathrm{~N}$ & $27.73 \mathrm{~N}$ & $\begin{array}{l}\text { Lempung } \\
\text { berliat }\end{array}$ & Vertisol & $1.07 \mathrm{~N}$ & $7.24 \mathrm{~N}$ & $225 \mathrm{~N}$ & $48.8 \mathrm{~N}$ & $0.17 \mathrm{~N}$ & $5.09 \mathrm{~N}$ & $2.0 \times 10^{7} \mathrm{~N}$ \\
\hline & $4 \mathrm{UL}_{2}$ & $60 \mathrm{~N}$ & 0 & 66.47 & $21.87 \mathrm{~N}$ & $11.66 \mathrm{~N}$ & $\begin{array}{l}\text { Lempung } \\
\text { berdebu }\end{array}$ & Vertisol & $1.01 \mathrm{~N}$ & $7.39 \mathrm{~N}$ & $223 \mathrm{~N}$ & $50.34 \mathrm{~N}$ & $0.105 \mathrm{~N}$ & $2.51 \mathrm{~N}$ & $4.6 \times 10^{8} \mathrm{~N}$ \\
\hline & $4 \mathrm{UL}_{3}$ & $60 \mathrm{~N}$ & 0 & 83.94 & $11.37 \mathrm{R}$ & $4.69 \mathrm{~N}$ & $\begin{array}{l}\text { Lempung } \\
\text { berdebu }\end{array}$ & Vertisol & $1.12 \mathrm{~N}$ & $7.58 \mathrm{~N}$ & $222 \mathrm{~N}$ & $49.16 \mathrm{~N}$ & $0.111 \mathrm{~N}$ & $0.69 \mathrm{R}$ & $4.95 \times 10^{2} \mathrm{~N}$ \\
\hline \multirow{3}{*}{5} & $5 \mathrm{UL} 1$ & $60 \mathrm{~N}$ & 0 & 29.66 & $58.54 \mathrm{~N}$ & $10.79 \mathrm{~N}$ & List & Vertisol & $1.11 \mathrm{~N}$ & $7.16 \mathrm{~N}$ & $122 \mathrm{R}$ & $45.05 \mathrm{~N}$ & $0.84 \mathrm{~N}$ & $0.09 \mathrm{R}$ & $3.4 \times 10^{6} \mathrm{~N}$ \\
\hline & $5 \mathrm{UL} 2$ & $100 \mathrm{~N}$ & 0 & 10.21 & $83.96 \mathrm{~N}$ & $5.83 \mathrm{~N}$ & Liat & Vertisol & $1.21 \mathrm{~N}$ & $7.36 \mathrm{~N}$ & $126 \mathrm{R}$ & $41.05 \mathrm{~N}$ & $0.62 \mathrm{~N}$ & $O R$ & $6.4 \times 10^{\circ} \mathrm{N}$ \\
\hline & $5 \mathrm{UL}_{3}$ & $100 \mathrm{~N}$ & 0 & 29.07 & $58.53 \mathrm{~N}$ & $11.46 \mathrm{~N}$ & Liat & Vertisol & $1.18 \mathrm{~N}$ & $7.24 \mathrm{~N}$ & $265 \mathrm{~N}$ & $41.29 \mathrm{~N}$ & $0.57 \mathrm{~N}$ & $1.16 \mathrm{~N}$ & $1.3 \times 10^{2} \mathrm{~N}$ \\
\hline \multirow{3}{*}{6} & $6 \mathrm{UL} 1$ & $100 \mathrm{~N}$ & 0 & 32.56 & $58.49 \mathrm{~N}$ & $8.72 \mathrm{~N}$ & Liat & Vertisol & $1.18 \mathrm{~N}$ & $7.06 \mathrm{~N}$ & $268 \mathrm{~N}$ & $46.61 \mathrm{~N}$ & $0.57 \mathrm{~N}$ & $0.21 \mathrm{R}$ & $3.8 \times 10^{6} \mathrm{~N}$ \\
\hline & $6 \mathrm{UL} 2$ & $100 \mathrm{~N}$ & 0 & 18.99 & $79.00 \mathrm{~N}$ & $2.01 \mathrm{~N}$ & Liat & Vertisol & $1.25 \mathrm{~N}$ & $7.4 \mathrm{~N}$ & $270 \mathrm{~N}$ & $44.47 \mathrm{~N}$ & $0.62 \mathrm{~N}$ & $0.73 \mathrm{~N}$ & $3.05 \times 10^{5} \mathrm{~N}$ \\
\hline & $6 \mathrm{UL}_{3}$ & $100 \mathrm{~N}$ & 0 & 39.32 & $58.18 \mathrm{~N}$ & $2.51 \mathrm{~N}$ & List & Vertisol & $1.23 \mathrm{~N}$ & $7.35 \mathrm{~N}$ & $265 \mathrm{~N}$ & $47.27 \mathrm{~N}$ & $0.94 \mathrm{~N}$ & $\mathrm{OR}$ & 3.0 x $10 \% \mathrm{Nate}$ \\
\hline
\end{tabular}

Sumber: Analisis laboratorium

Keterangan: $\mathrm{N}=$ Normal (di bawah ambang kritis) 
$\mathrm{R}=$ Rusak (di atas ambang kritis)

Tabel 7 Perhitungan skoring frekuensi relati kerusakan tanah SPL 1, 2, dan 3

\begin{tabular}{|c|c|c|c|c|c|c|c|c|c|c|c|c|c|c|c|c|}
\hline \multirow[b]{2}{*}{ No } & \multirow[b]{2}{*}{ Parameter } & \multicolumn{3}{|c|}{ SPL 1} & \multirow[b]{2}{*}{ Frekuensi } & \multirow[b]{2}{*}{ Skor } & \multicolumn{3}{|c|}{ SPL 2} & \multicolumn{7}{|c|}{ SPL 3} \\
\hline & & $\begin{array}{c}1 \mathrm{UL} \\
1\end{array}$ & $\begin{array}{c}1 \mathrm{UL} \\
2\end{array}$ & $\begin{array}{c}1 \mathrm{UL} \\
3 \\
\end{array}$ & & & $\begin{array}{c}2 \mathrm{UL} \\
1\end{array}$ & $\begin{array}{c}2 \mathrm{UL} \\
2\end{array}$ & $\begin{array}{c}2 \mathrm{UL} \\
3\end{array}$ & Frekuensi & Skor & $\begin{array}{c}3 \mathrm{UL} \\
1\end{array}$ & $\begin{array}{c}3 \mathrm{UL} \\
2\end{array}$ & $\begin{array}{c}3 \mathrm{UL} \\
3\end{array}$ & Frekuensi & Skor \\
\hline 1 & $\begin{array}{l}\text { Ketebalan Solum } \\
(\mathrm{cm})\end{array}$ & 100 & 100 & 100 & $0 / 3=0 \%$ & 0 & 70 & 70 & 70 & $0 / 3=0 \%$ & 0 & 60 & 60 & 60 & $0 / 3=0 \%$ & 0 \\
\hline 2 & $\begin{array}{l}\text { Kebatuan } \\
\text { permukaan (\%) }\end{array}$ & $0 \%$ & $0 \%$ & $0 \%$ & $0 / 3=0 \%$ & 0 & $0 \%$ & $0 \%$ & $0 \%$ & $0 / 3=0 \%$ & 0 & $0 \%$ & $0 \%$ & $0 \%$ & $0 / 3=0 \%$ & 0 \\
\hline \multirow[t]{3}{*}{3} & Tekstur & & & & & & & & & & & & & & & \\
\hline & Pasir (\%) & 6.94 & 16.98 & 0.42 & $0 / 3=0 \%$ & 0 & 19.17 & 36.32 & 26.59 & $0 / 3=0 \%$ & 0 & 17.31 & 11.98 & 23.14 & $0 / 3=0 \%$ & 0 \\
\hline & Klei (\%) & 64.34 & 69.46 & 76.56 & $0 / 3=0 \%$ & 0 & 34.34 & 9.05 & 11.65 & $2 / 3=66.7 \%$ & 3 & 47.23 & 12.82 & 28.76 & $1 / 3=33.3 \%$ & 2 \\
\hline 4 & $\begin{array}{l}\text { Berat volume } \\
\left(\mathrm{g} / \mathrm{cm}^{3}\right)\end{array}$ & 1.11 & 1 & 0.76 & $0 / 3=0 \%$ & 0 & 1.08 & 1.1 & 1.16 & $0 / 3=0 \%$ & 0 & 1.13 & 1.29 & 1.07 & $0 / 3=0 \%$ & 0 \\
\hline 5 & Porositas total (5) & 45.32 & 45.85 & 45.11 & $0 / 3=0 \%$ & 0 & 52.21 & 49.59 & 49.51 & $0 / 3=0 \%$ & 0 & 48.64 & 47.42 & 53.28 & $0 / 3=0 \%$ & 0 \\
\hline 6 & $\begin{array}{l}\text { Permeabilitas } \\
(\mathrm{cm} / \mathrm{jam})\end{array}$ & 3.47 & 0.51 & 0 & $2 / 3=66.7 \%$ & 3 & 0.16 & 1.37 & 0 & $2 / 3=66.7 \%$ & 3 & 0.35 & 0.49 & 0 & $3 / 3=100 \%$ & 4 \\
\hline 7 & $\mathrm{pH}$ & 6.51 & 6.62 & 7.15 & $0 / 3=0 \%$ & 0 & 7.19 & 7.28 & 7.34 & $0 / 3=0 \%$ & 0 & 6.79 & 7.54 & 7.22 & $0 / 3=0 \%$ & 0 \\
\hline 8 & $\mathrm{DHL}(\mathrm{mS} / \mathrm{cm})$ & 0.46 & 0.60 & 0.13 & $0 / 3=0 \%$ & 0 & 0.15 & 0.12 & 0.12 & $0 / 3=0 \%$ & 0 & 0.22 & 0.11 & 0.10 & $0 / 3=0 \%$ & 0 \\
\hline 9 & Redoks (mV) & 335 & 330 & 340 & $0 / 3=0 \%$ & 0 & 240 & 242 & 240 & $0 / 3=0 \%$ & 0 & 166 & 160 & 163 & $3 / 3=100 \%$ & 4 \\
\hline \multirow[t]{4}{*}{10} & $\begin{array}{l}\text { Jumlah mikroba } \\
\text { (cfu/g tanah) }\end{array}$ & $\begin{array}{l}1.6 \mathrm{x} \\
10^{7}\end{array}$ & $\begin{array}{l}3.9 \mathrm{x} \\
10^{6}\end{array}$ & $\begin{array}{l}3.05 x \\
10^{6}\end{array}$ & $0 / 3=0 \%$ & 0 & $\begin{array}{l}2.8 \mathrm{x} \\
10^{7}\end{array}$ & $\begin{array}{l}3.2 x \\
10^{6}\end{array}$ & $\begin{array}{l}3.9 \mathrm{x} \\
10^{6}\end{array}$ & $0 / 3=0 \%$ & 0 & $\begin{array}{l}8.2 x \\
10^{6}\end{array}$ & $\begin{array}{l}7.1 \mathrm{x} \\
10^{7}\end{array}$ & $\begin{array}{l}6.05 x \\
10^{6}\end{array}$ & $0 / 3=0 \%$ & 0 \\
\hline & Total Skor & & & & & 3 & & & & & 6 & & & & & 10 \\
\hline & Status & \multicolumn{4}{|c|}{ RI (Rusak Ringan) } & & \multicolumn{3}{|c|}{ RI (Rusak Ringan) } & & & \multicolumn{3}{|c|}{ RI (Rusak Ringan) } & & \\
\hline & Faktor Pembatas & \multicolumn{3}{|c|}{ Permeabilitas } & & & \multicolumn{3}{|c|}{ Tekstur dan Permeabilitas } & & & \multicolumn{3}{|c|}{$\begin{array}{l}\text { RI (Rusak Ringan) } \\
\text { Tekstur, Permeabilitas, dar }\end{array}$} & Redoks & \\
\hline
\end{tabular}

Sumber : Analisis laboratorium

Keterangan: UL: Ulangan

Tabel 8 Perhitungan skoring frekuensi relati kerusakan tanah SPL 4, 5, dan 6

\begin{tabular}{|c|c|c|c|c|c|c|c|c|c|c|c|c|c|c|c|c|}
\hline \multirow[b]{2}{*}{ No } & \multirow[b]{2}{*}{ Parameter } & \multicolumn{3}{|c|}{ SPL 4} & \multirow[b]{2}{*}{ Frekuensi } & \multirow[b]{2}{*}{ Skor } & \multicolumn{3}{|c|}{ SPL 5} & \multicolumn{7}{|c|}{ SPL 6} \\
\hline & & $\begin{array}{l}4 \text { UL } \\
1\end{array}$ & $\begin{array}{l}4 U \mathrm{UL} \\
2\end{array}$ & $\begin{array}{l}4 \text { UL } \\
3\end{array}$ & & & $\begin{array}{l}5 \mathrm{UL} \\
1\end{array}$ & $\begin{array}{l}5 \text { UL } \\
2\end{array}$ & $\begin{array}{l}5 \mathrm{UL} \\
3\end{array}$ & Frekuensi & Skor & $\begin{array}{l}6 \mathrm{UL} \\
1\end{array}$ & $\begin{array}{l}6 \mathrm{UL} \\
2\end{array}$ & $\begin{array}{l}6 \mathrm{UL} \\
3\end{array}$ & Frekuensi & Skor \\
\hline 1 & $\begin{array}{l}\text { Ketebalan Solum } \\
(\mathrm{cm})\end{array}$ & 60 & 60 & 60 & $0 / 3=0 \%$ & 0 & 60 & 100 & 100 & $0 / 3=0 \%$ & 0 & 100 & 100 & 100 & $0 / 3=0 \%$ & 0 \\
\hline 2 & $\begin{array}{l}\text { Kebatuan } \\
\text { permukaan (\%) }\end{array}$ & $0 \%$ & $0 \%$ & $0 \%$ & $0 / 3=0 \%$ & 0 & $0 \%$ & $0 \%$ & $0 \%$ & $0 / 3=0 \%$ & 0 & $0 \%$ & $0 \%$ & $0 \%$ & $0 / 3=0 \%$ & 0 \\
\hline \multirow[t]{2}{*}{3} & Tekstur & & & & & & & & & & & & & & & \\
\hline & Pasir (\%) & 27.73 & 11.66 & 4.69 & $0 / 3=0 \%$ & 0 & 10.79 & 5.83 & 11.46 & $0 / 3=0 \%$ & 0 & 8.72 & 2.01 & 2.51 & $0 / 3=0 \%$ & 0 \\
\hline 4 & $\begin{array}{l}\text { Berat volume } \\
\left(\mathrm{g} / \mathrm{cm}^{3}\right)\end{array}$ & 1.07 & 1.01 & 1.12 & $0 / 3=0 \%$ & 0 & 1.11 & 1.21 & 1.18 & $0 / 3=0 \%$ & 0 & 1.18 & 1.25 & 1.23 & $0 / 3=0 \%$ & 0 \\
\hline 5 & Porositas total (\%) & 48.80 & 50.34 & 49.16 & $0 / 3=0 \%$ & 0 & 45.05 & 41.05 & 41.29 & $0 / 3=0 \%$ & 0 & 46.61 & 44.47 & 47.27 & $0 / 3=0 \%$ & 0 \\
\hline 6 & $\begin{array}{l}\text { Permeabilitas } \\
(\mathrm{cm} / \mathrm{jam})\end{array}$ & 5.09 & 2.51 & 0.7 & $1 / 3=33.3 \%$ & 2 & 0.09 & $0 R$ & 1.16 & $2 / 3=66.7 \%$ & 3 & 0.21 & 0.73 & 0 & $2 / 3=66.7 \%$ & 3 \\
\hline 7 & $\mathrm{pH}$ & 7.24 & 7.39 & 7.58 & $0 / 3=0 \%$ & 0 & 7.16 & 7.36 & 7.24 & $0 / 3=0 \%$ & 0 & 7.06 & 7.40 & 7.35 & $0 / 3=0 \%$ & 0 \\
\hline 8 & $\mathrm{DHL}(\mathrm{mS} / \mathrm{cm})$ & 0.17 & 0.11 & 0.11 & $0 / 3=0 \%$ & 0 & 0.84 & 0.62 & 0.57 & $0 / 3=0 \%$ & 0 & 0.57 & 0.62 & 0.94 & $0 / 3=0 \%$ & 0 \\
\hline \multirow[t]{4}{*}{10} & $\begin{array}{l}\text { Jumlah mikroba } \\
\text { (cfu/g tanah) }\end{array}$ & $\begin{array}{l}2.0 x \\
10^{7}\end{array}$ & $\begin{array}{l}4.6 \mathrm{x} \\
10^{6}\end{array}$ & $\begin{array}{l}4.95 \\
\times 10^{8}\end{array}$ & $0 / 3=0 \%$ & 0 & $\begin{array}{l}3.4 \mathrm{x} \\
10^{6}\end{array}$ & $\begin{array}{l}6.4 x \\
10^{6}\end{array}$ & $\begin{array}{l}1.3 \mathrm{x} \\
10^{8}\end{array}$ & $0 / 3=0 \%$ & 0 & $\begin{array}{l}3.8 x \\
10^{6}\end{array}$ & $\begin{array}{l}3.05 x \\
10^{6}\end{array}$ & $\begin{array}{l}3.0 x \\
10^{6}\end{array}$ & $0 / 3=0 \%$ & 0 \\
\hline & Total Skor & & & & & 4 & & & & & 6 & & & & & 3 \\
\hline & Status & \multicolumn{4}{|c|}{ RI (Rusak Ringan) } & & \multicolumn{3}{|c|}{ RI (Rusak Ringan) } & & & \multicolumn{3}{|c|}{ RI (Rusak Ringan) } & & \\
\hline & Faktor Pembatas & \multicolumn{4}{|c|}{ Tekstur dan Permeabilitas } & & \multicolumn{4}{|c|}{ Permeabilitas dan Redoks } & & \multicolumn{3}{|c|}{ Permeabilitas } & & \\
\hline
\end{tabular}

Sumber : Analisis laboratorium

Keterangan: UL: Ulangan

Hasil laboratorium yang telah di matching (Tabel 8), selanjutnya dilakukan tahap skoring frekuensi relatif setiap parameter kerusakan tanah dan penjumlahan hasil skoring. Hasil perhitungan skoring frekuensi relatif kerusakan tanah, kemudian dilakukan penetapan status kerusakan tanah dari hasil skoring dan penjumlahan skoring (Tabel 9 dan Tabel 10.) yang mengacu pada Kementerian Negara Lingkungan Hidup (2009).

Hasil skoring dari setiap parameter kerusakan tanah untuk produksi biomassa di Kecamatan Padas menunjukkan bahwa SPL 1 termasuk kedalam status kerusakan tanah RI (Rusak ringan) dengan faktor pembatas permeabilitas. Seluruh parameter kerusakan tanah pada SPL 1 termasuk kedalam status tidak rusak atau dibawah ambang kritis, namun untuk parameter permeabilitas termasuk kedalam status ambang kritis karena memiliki nilai diatas ambang kritis dengan frekuensi relatif sebesar $66,7 \%$ dan total skor sebesar 3 . SPL 2 termasuk kedalam status kerusakan tanah RI (Rusak ringan) dengan faktor pembatas tekstur dan permeabilitas. Seluruh parameter kerusakan tanah 
pada SPL 2 termasuk kedalam status tidak rusak atau dibawah ambang kritis, namun untuk parameter tekstur dan permeabilitas termasuk kedalam status ambang kritis karena memiliki nilai diatas ambang kritis dengan frekuensi relatif masing-masing sebesar $66,7 \%$ dan total skor sebesar 6 .

SPL 3 termasuk kedalam status kerusakan tanah RI (Rusak ringan) dengan faktor pembatas tekstur, permeabilitas, dan redoks. Seluruh parameter kerusakan tanah pada SPL 3 termasuk kedalam status tidak rusak atau dibawah ambang kritis, namun untuk parameter tekstur, permeabilitas, dan redoks termasuk kedalam status ambang kritis karena memiliki nilai diatas ambang kritis dengan frekuensi relatif masingmasing sebesar $33,3 \%, 100 \%$, dan $100 \%$, total skor ketiga faktor pembatas sebesar 10. SPL 4 termasuk kedalam status kerusakan tanah RI (Rusak ringan) dengan faktor pembatas permeabilitas. Seluruh parameter kerusakan tanah pada SPL 4 termasuk kedalam status tidak rusak atau dibawah ambang kritis, namun untuk parameter tekstur dan permeabilitas termasuk kedalam status ambang kritis karena memiliki nilai diatas ambang kritis dengan frekuensi relatif masing-masing sebesar 33,3\% dan 33,3\%, total skor dari kedua faktor pembatas yaitu sebesar 4 .

SPL 5 termasuk kedalam status kerusakan tanah $\mathrm{RI}$ (Rusak ringan) dengan faktor pembatas permeabilitas. Seluruh parameter kerusakan tanah pada SPL 5 termasuk kedalam status tidak rusak atau dibawah ambang kritis, namun untuk parameter permeabilitas dan redoks termasuk kedalam status ambang kritis karena memiliki nilai diatas ambang kritis dengan frekuensi relatif masing-masing sebesar $66,7 \%$ dan total skor kedua faktor pembatas sebesar 6 . SPL 6 termasuk kedalam status kerusakan tanah RI (Rusak ringan) dengan faktor pembatas permeabilitas. Seluruh parameter kerusakan tanah pada SPL 6 termasuk kedalam status tidak rusak atau dibawah ambang kritis, namun untuk parameter permeabilitas termasuk kedalam status ambang kritis karena memiliki nilai diatas ambang kritis dengan frekuensi relatif sebesar $66,7 \%$ dan total skor sebesar 3 .

Hasil dari semua SPL menunjukkan bahwa semua SPL di Kecamatan Padas memiliki status kerusakan tanah RI (Rusak ringan) (Gambar 2). SPL 1 dan SPL 6 memiliki faktor pembatas permeabilitas dengan luas 558,7 ha atau $9,43 \%$. SPL 2 dan SPL 4 dengan faktor pembatas tekstur dan permeabilitas memiliki luas 646,3 ha atau $10,91 \%$. SPL 3 dengan faktor pembatas tekstur, permeabilitas, dan redoks memiliki luas 85,7 ha atau $1,45 \%$. SPL 5 dengan faktor pembatas permeabilitas dan redoks memiliki luas 3462,5 ha atau $58,45 \%$ kemudian bukan wilayah efektif seluas 1171 ha atau $19,77 \%$. Permeabilitas yang muncul sebagai faktor pembatas disetiap SPL, hal tersebut berkaitan dengan tekstur tanah di wilayah penelitian yang bertektur liat.

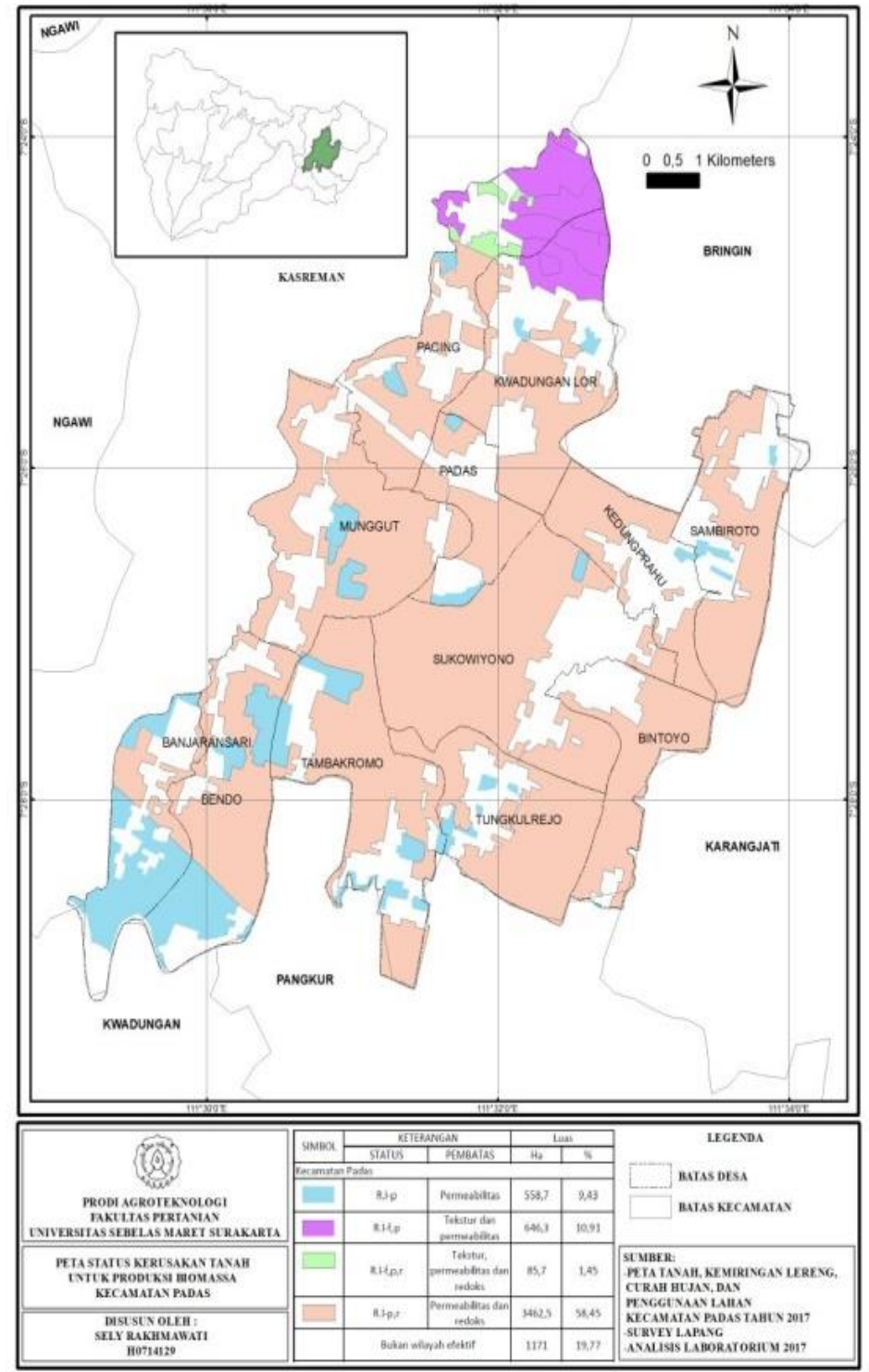

Gambar 2 Peta status kerusakan tanah Kecamatan Padas

Hasil penelitian oleh Yulnafatmawita et al. (2007) menyatakan bahwa semakin liat tanah maka akan semakin rendah laju permeabilitas tanah. Pernyataan tersebut dilanjutkan dengan hasil penelitian Yulnafatmawita et al. (2008), bahan organik dapat digunakan untuk memperbaiki permeabilitas tanah. Kandungan bahan organik yang tinggi pada lapisan permukaan $(0-20 \mathrm{~cm})$ dapat meningkatkan permeabilitas tanah. Hal tersebut disebabkan karena bahan organik mampu menciptakan aggregate yang mantap dengan tipe struktur yang remah, yaitu mempunyai keseimbangan pori makro dan mikro.

\section{KESIMPULAN DAN SARAN}

\section{KESIMPULAN}

1. Parameter yang menyumbang kerusakan tanah di Kecamatan Padas yaitu permeabilitas di semua SPL, parameter tekstur di SPL 2, 3, dan 4, kemudian parameter redoks tanah di SPL 3 dan 5.

2. Kecamatan Padas Kabupaten Ngawi pada semua SPL termasuk kedalam status rusak ringan (RI) sesuai dengan acuan PP No. 150 Tahun 2000. 


\section{SARAN}

Upaya perbaikan yang dapat dilakukan pada wilayah penelitian dengan dominasi fraksi klei adalah dengan penambahan bahan organik yang bertujuan menciptakan aggregate yang mantap dengan tipe struktur yang remah, yaitu mempunyai keseimbangan pori makro dan mikro. Selanjutnya untuk menjaga kualitas tanah lebih lama maka jumlah unsur hara yang diambil dari tanah harus sama dengan masukan unsur hara ke dalam tanah.

\section{DAFTAR PUSTAKA}

Belachew T. and Y. Abera, 2010. Assessment of soil fertility status with depth in wheat growing highlands of southeast Ethiopia. J. Agricultural sciences 6 (5):525-531.

Boix, L.C. and J.A. Zinck. 2008. Land-use planning in the chaco plain (Burruyacu, Argentina). Part 1: Evaluating land-use options to support crop diversification in an agricultural frontier area Using physical land evaluation. J. Environmental Management 42:1043-1063.

BPS [Badan Pusat Statistik Indonesia]. 2015. Statistik Indonesia. Badan Pusat Statistik Indonesia. Jakarta.

BPS [Badan Pusat Statistik Indonesia]. 2015. Hasil survei penduduk antar sensus 2015. Badan Pusat Statistik Indonesia. Jakarta

BPS [Badan Pusat Statistik] Kab. Ngawi. 2015. Ngawi dalam angka. Badan Pusat Statistik Kab. Ngawi. Ngawi.

De la Rosa, D. 2005. Soil quality evaluation and monitoring based on land evaluation. Land degrad develop 16: 551-559.

Fahmi A, Hanudin E. 2008. Pengaruh kondisi redoks terhadap stabilitas komplek organik-besi pada tanah sulfat masam. J Ilmu tanah dan lingkungan 8 (1): 4955.

Foth D. Henry. 1994. Dasar dasar ilmu tanah. Erlangga. Jakarta.

H.P.S. Abdul K. et al. 2015. The role of soil properties and it's interaction towards quality plant fiber: review. $J$. Renewable and sustainable energy reviews 43 : 1006-1015.

Kementerian Negara Lingkungan Hidup Republik Indonesia. 2009. Pedoman Teknis Penyusunan Peta Status Kerusakan Tanah Untuk Produksi Biomasa. Jakarta.

Kusumaningtyas S. A, Cahyono P, Sudarto, Suntari R. 2015. Pengaruh tinggi muka air terhadap $\mathrm{pH}$, Eh, $\mathrm{Fe}$ $A l^{\text {dd }}, \mathrm{Mn}$ dan $\mathrm{P}$ terlarut pada tanaman nanas klon GP3 di ultisol. J Tanah dan sumberdaya lahan 2 (1): 103-109.

Lehmann, A. and K. Stahr. 2010. The potential of soil functions and planner-oriented soil evaluation to achieve sustainable land use. J Soils Sediments 10:1092-1102.
Peraturan Menteri Negara Lingkungan Hidup Nomor 20 Tahun 2008 Tentang Petunjuk teknis Standar Pelayanan Minimal Bidang Lingkungan Hidup Daerah Kabupaten/Kota.

Peraturan Pemerintah Lingkungan Hidup Nomor 7 Tahun 2006 Tentang Tata Cara Pengukuran Kreteria Baku Kerusakan Tanah.

Peraturan Pemerintah Republik Indonesia Tahun 150 Tahun 2000 Tentang Pengendalian Kerusakan Tanah Untuk Produksi Biomassa.

Rogero, O.M., Basa, Christian A.C., Emerito, R., Otadoy, dan Violanda, R. 2013. Investigation of the effect of water content on the bulk soil electrical conductivity (EC) of loam using wenner array method. APJSME 1 (1): 12-14.

Rosie CC, Gavrilescu M, Macoveanu M. 2008. Biomass an important renewable source of energy in Romania. J. Environtmental engineering and management 7 (5): 559-568.

Seladji, S., Cosenza, P., Tabbagh, A., Ranger, J., dan Richard, G. 2010. The effect of compaction on soil electrical resistivity: a laboratory investigation. European Journal of Soil Science 61:1-13. doi: 10.1111/j.1365-2389.2010.01309.x.

Suntari, R., R. Retnowati, Sumarno, M. Munir. 2003. The effect of flooding and application of different urea on soil chemical properties and $\mathrm{N}$-available $\left(\mathrm{NH}_{4}{ }^{+}\right.$dan $\left.\mathrm{NO}_{3}{ }^{-}\right)$on vertisol. International journal of ecosystem 3 (6): 196-202.

Virginia Cooperative Extension. 2009. Agricultural management practices and soil quality. Virginia state university. Amerika (US).

Xiong I., J.K. Zhu. 2002. Salt tolerance in the aradibopsis. American society of plant biologist.

Yulnafatmawita, Luki U., Yana A. 2007. Kajian sifat fisika tanah beberapa penggunaan lahan di bukit Gajahbuih kawasan hutan hujan teropik gunung Gadut Padang. J Solum 4 (2): 49-6.

Yokoyama S. 2008. Panduan untuk Produksi dan Pemanfaatan Biomassa. The Japan Institue of Energy. Jepang (IN). 
